\title{
The Geology, Stratigraphy and Structure of Ma'an Area, South Jordan
}

\author{
Tarawneh, K. \\ Faculty of Engineering, Amman Arab University, P. O. Box 2234, Amman, Jordan
}

\begin{abstract}
This study focused on the geology, stratigraphy and structure of the Ma'an area at the coordinates: 350 30/350 45 / E 300 00/-300 15/ N. Field and laboratory studies have been carried out with aim to get a better understanding on the main geological features at the study area. Therefore, the importance of this study is due to the fact that Jordan is witnessing an expansion in investment in the extractive and exploration industries, and Ma'an Governorate is considered as a huge reservoir of mineral and industrial rocks that will play an important role on mining industries in Jordan. Rocks like phosphate, limestone, coquina, clay, dolomite, sandstone and different types of aggregates are the main source for many industries in the area.The study area is located at $210 \mathrm{~km}$ south of Amman and is covered mainly by sedimentary rocks. This study includes a detailed explanation of the sedimentary rocks covering the whole area, including the Ajloun group which consist the Wadi Sir Limestone Formation, and the Balqa group which consist the following formations: Umm Al-Ghudran, Amman Silisicified Limestone, Al Hisa Phosphorite, Muwaqqar Chalk Marl and Umm Rijam Chert Limestone, as well as the lake sediments which appear in different localities in the study area .The study also includes the most important geological structures, where the most prominent direction of these structures are the north-south, northeastsouthwest, northwest and southeast faults, with few folds in different parts of the region.
\end{abstract}

Keywords: Ma'an, sedimentary, formation, lake, structure

DOI: $10.7176 / \mathrm{JEES} / 9-3-10$

Publication date:March $31^{\text {st }} 2019$

\section{Introduction}

Ma'an area covers about $660 \mathrm{Km}^{2}$ and forms part of the Central Jordan plateau, as well as the eastern part of Ash Shawbak mountainous ridge. The study area is situated $210 \mathrm{~km}$ south of Amman and $150 \mathrm{~km}$ northeast of Aqaba City. The study area defined by following coordinates $35^{0} 30^{\prime}-35^{0} 45^{\prime} \mathrm{E}$ and $30^{\circ} 00^{\prime}-30^{0} 15^{\prime} \mathrm{N}$ (Fig. 1). The area is characterized by moderate to flat relief, except the northwestern and southwestern parts. The elevation varies from $1630 \mathrm{~m}$ (above sea level) in the southeastern part to $1104 \mathrm{~m}$ in the eastern part of the study area. The drainage of the area is of moderate relief and affected by morphological rises and regional structures. Generally, the altitude falls gently eastwards and southwards. Many wadis drain to the east and southeast. Ma'an area includes two regional physiographic provinces (Burdon 1959; Bender 1974). These are the Central Jordan Pediplain and the Highlands east of the Rift. The highlands are of moderate relief forming the highest ground in the area:1630 $\mathrm{m}$ at Jibal El Fuweili (southwest).

Ma'an area falls in an arid climate zone. Rainfall is erratic both spatially and temporally. The study area characterized by Saharan climate, whereas the western and northwestern parts gets more rainfall. However, the region has a short rainy winter (December to March) and the rest of the year is warm and dry. The area gets an annual rainfall of $77 \mathrm{~mm}$. The amount of rain increases west and northwestwards. The mean annual temperature is $24 \mathrm{C}^{0}$. 


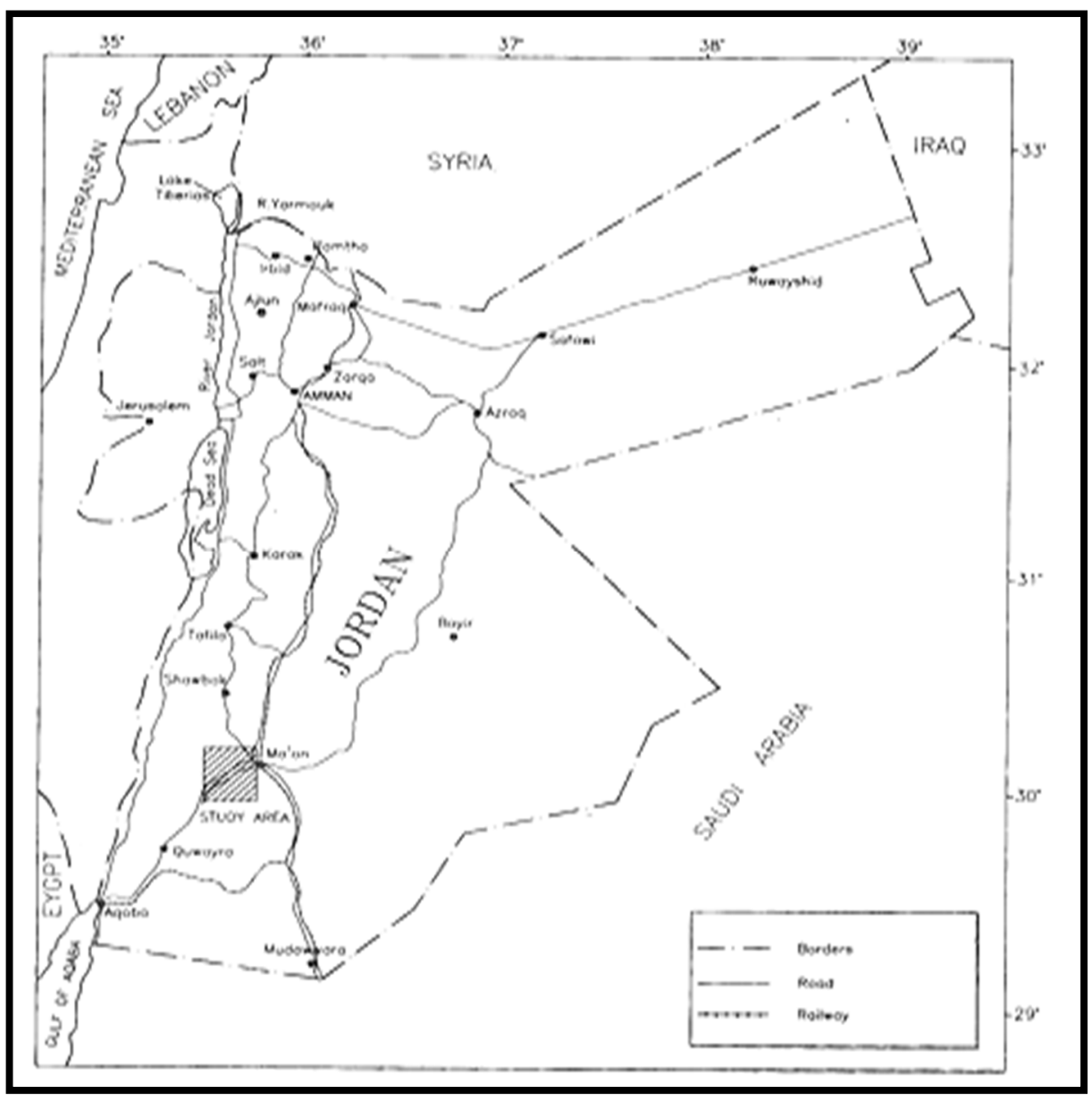

Figure 1. Location map of the study area

\section{Geological Setting and Previous Geological Studies}

\subsection{Geological Setting}

Ma'an area is mostly covered by sedimentary rocks spanning from Turonian-Eocene to Quaternary age. Sedimentation in the study area during the Mesozoic and early Cenozoic times was controlled by the configuration of the Tethys Sea and eustatic fluctuations of Arabian-Nubian Shield. A major transgression took place in Mesozoic to early Cenozoic resulting in deposition of fully marine carbonate and sandy facies sediments (Ajlun and Belqa Groups) (Fig. 2). The Wadi As Sir, Wadi Umm Ghudran, Amman Silicified Limestone and Al Hisa Phosphorite formations dominate the northwestern and southwestern parts and partly in the central part of the study area. The overlaying Muwaqqar Chalk Marl (Maastrichitian-Paleocene) and Umm Rijam Chert Limestone (Eocene) formations cover broad areas of the study area. Shallow lakes are existed in many parts of the study area as well as in Ma'an City, at the periphery of Jabal El Whehida, south of v. Fardach, east of Jabal El Jitheh and along the road between Ma'an and Ail. Superficial sediments (Pleistocene to Recent) cover considerable parts of the study area and include alluvium, wadi sediments and lake sediments. N-S, NE-SW and NW-SE trending faults are the principal structural elements of the area. Folding and flextures with anticlines and synclines mostly trending NE-SW and N-S are present. The structural pattern in the area is controlled by the Dead Sea Transform Fault System. 


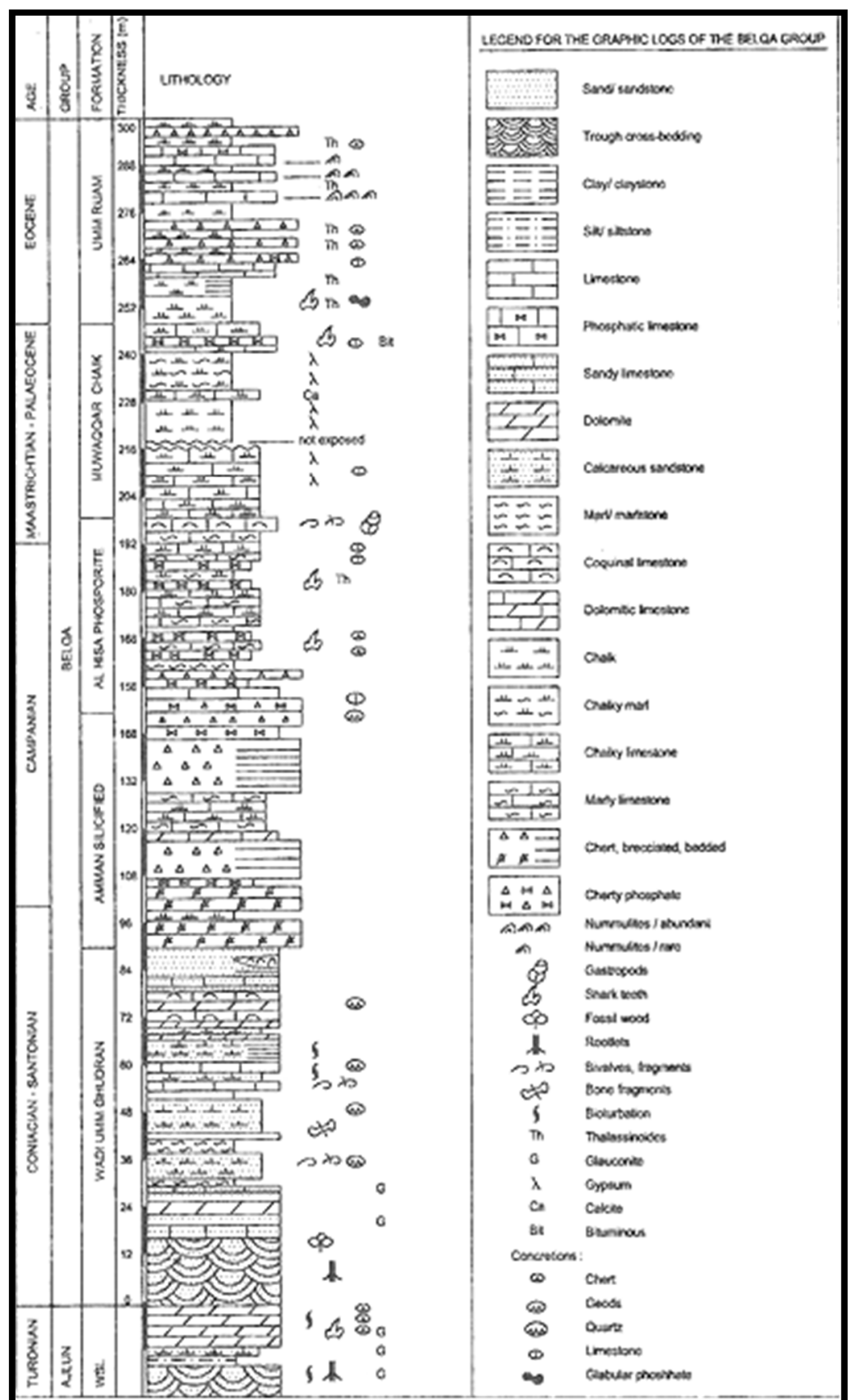

Figure 2. Graphic log of the Belqa Group and upper part of the Ajlun group in the study area

\subsection{Methods of Investigation}

A number of stages were carried out to study the exposed sediments in Ma'an area. Fieldwork was based on various scale aerial photographs 1: 25,000, 1:60,000, 1:50,000 topographic sheet and 1:50,000 landsat image. Interpretation of aerial photographs of the study area was undertaken prior to the fieldwork to identify the geologic units, boundaries and structural pattern. For the objectives of this work, field data were collected during systematic field trips. Data obtained from the aerial photographs were transferred to 1:50,000 scale for the final drafting and produce the geological map for publication. Six lithological logs of various stratigraphic units were measured to ascertain the lateral variations. Representative samples of the sedimentary rocks exposed in the study area were collected and examined in the laboratory including petrographic and mineralogical examinations.

\section{Stratified Rocks}

\subsection{Lithostratigraphical Nomenclature}

The lithostratigraphical nomenclature used here is that adopted by Natural Resources Authority 1:50000 Geological Mapping Project. The sequence of lithological units exposed in Ma'an area is considered in detail in 
the following sections.

\subsection{Lithostratigraphy}

The exposed rock units in the mapped area are represented by the Ajlun Group represented by Wadi As Sir Formation with Turonian age and the Belqa Group represented by Wadi Umm Ghudran, Amman Silcified Limestone, Al Hisa Phosphorite, Muwaqqar Chalk Marl and Umm Rijam Chert Limestone formations, ranging from Coniacian to Eocene in age. Quaternary sediments and superficial deposits cover scattered parts of the study area. The chronological sequence of the lithological units present in Ma'an area is shown in Table 1.

Table 1. : Lithostratigraphical nomenclature of the stratified rocks in the study area.

\begin{tabular}{|c|c|c|c|c|}
\hline Era & Period & Epoch & Group & Formation \\
\hline $\begin{array}{l}\text { U } \\
\text { O } \\
\text { O } \\
\text { 帘 }\end{array}$ & 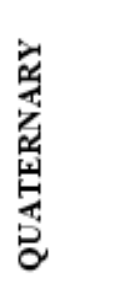 & Holocene & \multirow{5}{*}{ 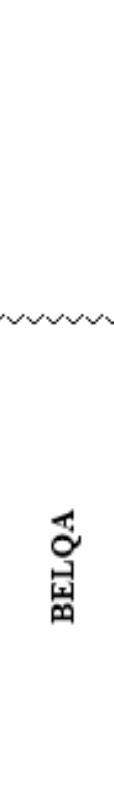 } & $\begin{array}{l}\text { Lake Sediments, Pleistocene Gravels, } \\
\text { Alluvial and Wadi Sediments, Alluvial Fans. }\end{array}$ \\
\hline \multirow{5}{*}{ 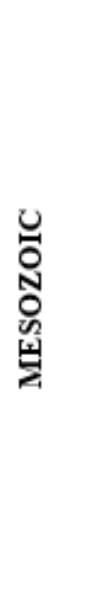 } & \multirow{5}{*}{ 选 } & Eocene & & Umm Rijam Chert Limestone \\
\hline & & Maastrichtian & & Muwaqqar Chalk Marl \\
\hline & & & & Al Hisa Phosphorite \\
\hline & & & & Amman Silicified Limestone \\
\hline & & $\begin{array}{l}\text { Coniacian- } \\
\text { Santonian } \\
\text { Turonian }\end{array}$ & 写 & $\begin{array}{l}\text { Wadi Umm Ghudran } \\
\text { Wadi As Sir Limestone }\end{array}$ \\
\hline
\end{tabular}

\subsubsection{Ajlun Group}

The Ajlun Group in the study area is represented by Wadi As Sir Limestone Formation (WSL). Formal description of the Ajlun Group can be found in Powell (1989). Wadi As Sir Limestone Formation is exposed in the northwestern and southwestern parts of the study area (Fig. 3). WSL is equivalent to the upper part of the Ajlun Series, which was first described by (MacDonald et al. 1965). Moumani (2000) used A7 as an equivalent to the Wadi As Sir limestone Formation. The German Geological Mission (1961-1966) considered the Echinoid limestone Unit and part of the Massive or Sandy Limestone Unit as equivalent to the WSL Formation (Bender 1974) (Table. 1). 


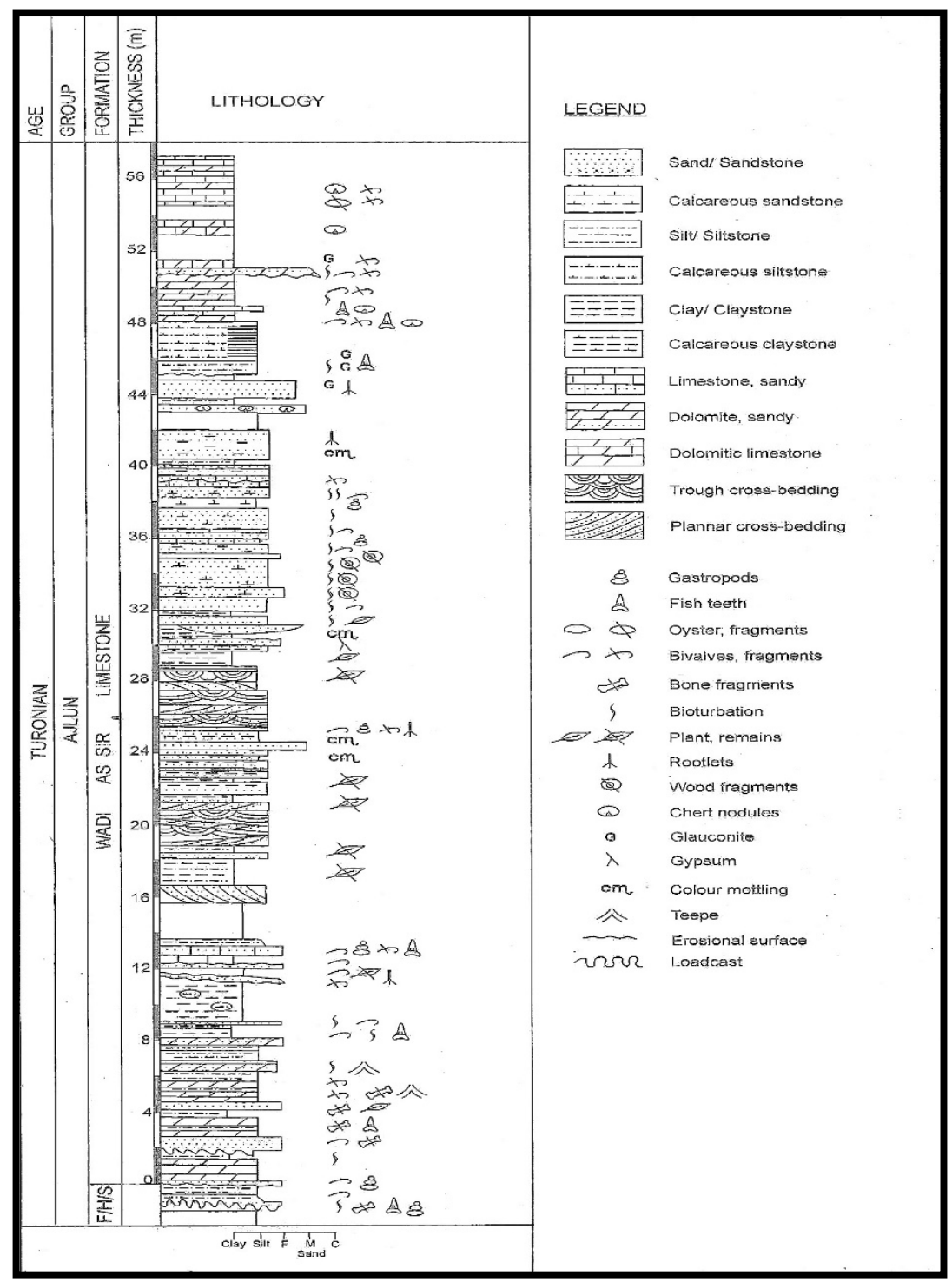

Figure 3. Graphic log of Wadi As Sir Limestone Formation along the border with Jabal Al Batra area (Moumani, et al. 2001).

Generally, the formation consists of dolomitic limestone, grey dolomite, yellow sandy dolomite, calcareous sandstone and chert concretions at the top (Fig 4). In the meantime, clearly indicate lateral variation in the higher sandy content in the southwestern part of the study area. No sections of this formation were measured in NW part of the study area due to the poor local and narrow exposure. The formation is up to $40 \mathrm{~m}$ thick in Basta village, whereas in the southwestern part of the area it is up to $60 \mathrm{~m}$ thick. The formation includes of macrofossils of bivalves, echinoids and gastropods. The macrofauna is most common in the thin-bedded limestone. A list of microfauna are given in (Bender 1974), who indicate a Turonian-Santonian age for this formation. The presence of bivalves, gastropods and echinoids in a lithology dominated by wackestone-packstone and sacharoidal dolomite with subordinate beds of grey chert nodules suggests a marine, subtidal environment of deposition (Powell 1989). 


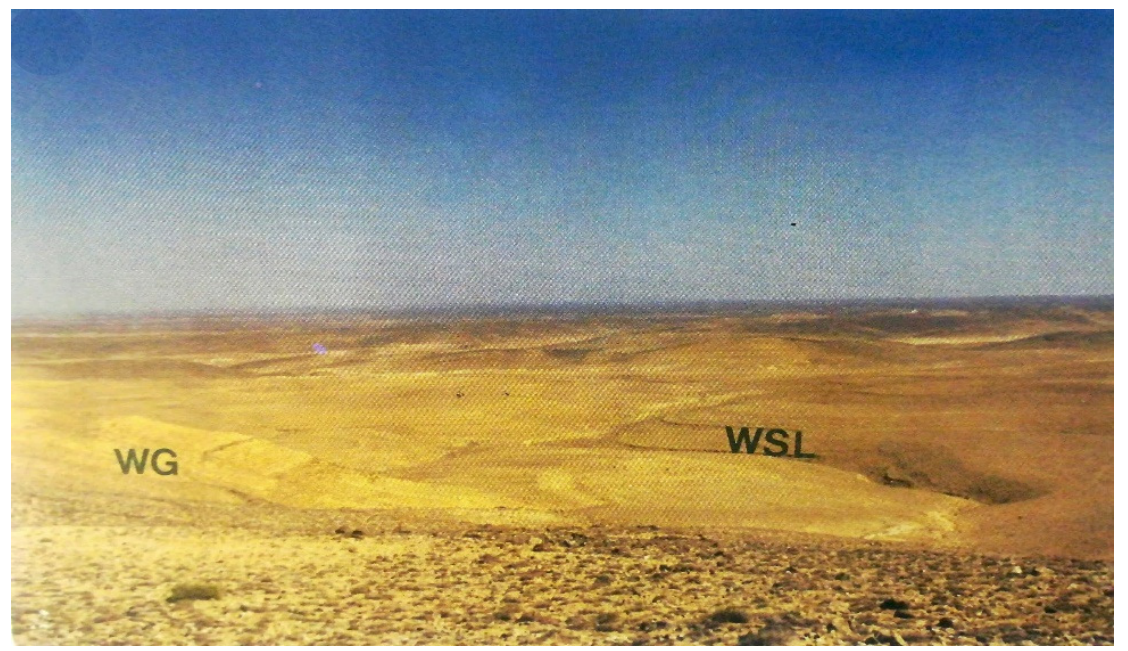

Figure 4. View shows the contact between Wadi Umm-Ghudran Formation (WG) and Wadi As Sir limestone Formation (WSL).

\subsubsection{Belqa Group}

Formal description of the Belqa Group can be found in Powell (Bender 1974). The Belqa Group in the study area comprises the following formations in ascending order: Wadi Umm Ghudran, Amman Silicified, Al Hisa Phosphorite, Muwaqqar Chalk Marl and Umm Rijam Chert Limestone (Fig. 2). Quaternary lake sediments overlie the Belqa Group in the northern part of the study area. Description of these formations is given in order of stratigraphic sequence as following:

\subsubsection{Wadi Umm Ghudran Formation (WUG)}

Wadi Umm Ghudran Formation cropsout in the northwestern and western parts of the area (Ail, Sadaqa and Basta villages) along the border with Bir Khidad and Ras An Naqab sheets and in the southwestern part of the area along the border with Jabal Al Batra (Jibal Thlaja) area. Generally, this formation forms steep slopes, due to the presence of hard quartz sandstone and chert, while the upper part produce gentle slopes due to the presence of chalk and sand (Fig. 5). Wadi Umm Ghudran Formation was measured in the southwestern part of the study area; very close to the border with Jabal Al Batra (Jibal Thlaja) area (Fig. 5). Generally, this formation characterized by lateral changes in facies from north to the south. However, in the northwestern part of the area this formation dominated by sandy dolomite, chalk to chalky limestone, guartzitic sandstone, chert beds and partly marly clay with glauconite and local variegated sand, while in the southwestern part of the area the formation becomes increasingly rich in quartz sand package and mostly consist of quartzite, quartzitic sandstone, phosphatic sand, calcareous sandstone, sandy coquinal limestone and thin layers of green clay (glauconite). The maximum measured thickness for this formation is up to $90 \mathrm{~m}$ in the study area. The macrofossils present in this formation contain shark teeth, bones and bivalves. Shark teeth are common in the quartzitic sand and sandy dolomitic beds. Thalassinoids burrows are present in sandy beds. Tree trunk (up to $7 \mathrm{~m}$ length and $0.30 \mathrm{~m}$ in diameter) was discovered by Moumani, et al. (2001) on the surface and insitu with their fruits in some localities. Parker (1970) assigned the formation to be of Santonian age, whereas Powell (1989) indicates a possible late Coniacian-Campanian age range. 


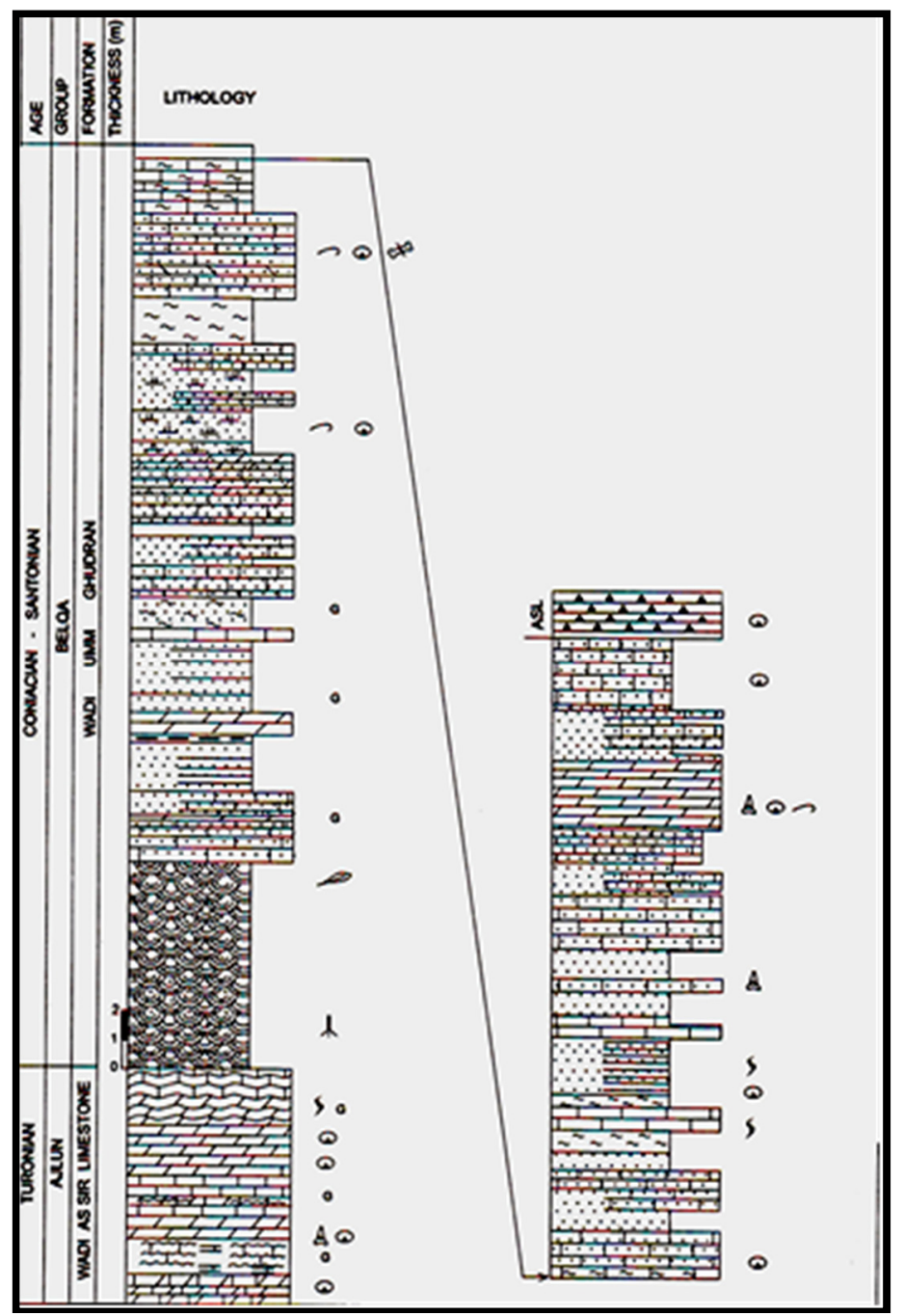

Figure 5. Graphic log of Wadi Umm Ghudran Formation in the study area.

\subsubsection{Amman Silicified Limestone Formation (ASL)}

The formation crops out in the northwestern part of the study area along the borders with Bir Khidad and Ras En Naqab sheet areas, and in the southwestern part along the border with Jabal Al Batra (jibal Thlaja) and Ras EnNaqab sheets areas, and in the central part in Wadi El Husianan and El Muriagha (Fig. 6). The formation consists of hard chert beds producing a distinctive landform of well-stratified rocks with steep slopes. The formation is locally characterized by small to medium scale synsedimentary folds (undulations) that are predominant in central Jordan. The Amman Silicified Limestone Formation was named after Amman City where the formation has a broad distribution. According the National 1:50,000 Mapping Project the term Amman Silicified Limestone Formation is equivalent to the middle part of Amman Formation (Masri 1963). The formation was logged in two localities in Basta village in northwestern part and in the southwestern part of the area, east of Murigha village (Fig. 7). The lowermost part of this formation consists of massive hard, dark grey autobrecciated chert interbedded with limestone and dolomitic limestone. The middle part is composed of thin-bedded with autobrecciated chert and thin layers of phosphates, phosphatic limestone, coquinal limestone, and phosphatic chert, whereas the phosphate increasing upwards. Quartz concretions are present in the southern part of the study area. From Ras An Naqab to Batn El Ghul including the study area the formation gradually thins out and passes laterally into a siliciclastic sandy. The macro and microfossils indicate that the Amman Formation has Campanian age (Morton \& Wetzel 1959; Bender 1974). The presence of coquina and chert indicate that such lithologies were probably deposited as pelagic laminated siliceous oozes (Powell 1989a). The presence of macro fauna and coquinal limestone suggests a shallow to deep-water subtidal marine environment of fluctuating water (Powell 1989). 


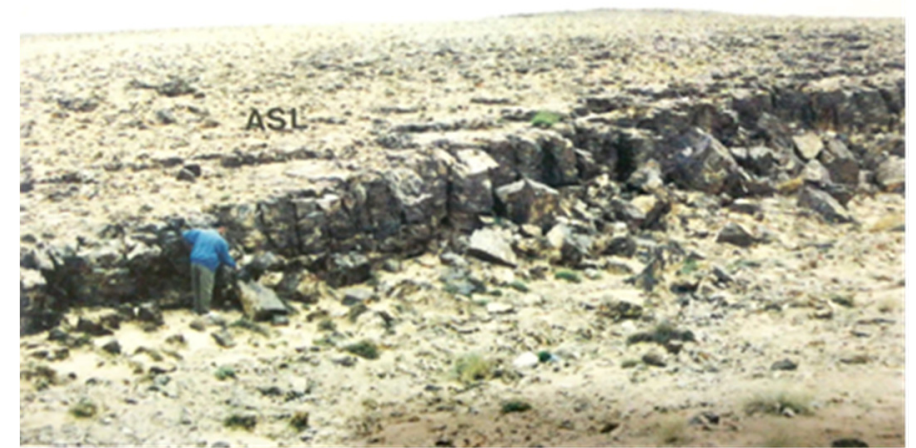

Figure 6. Exposure of the Amman Silicified Limestone Formation (ASL).

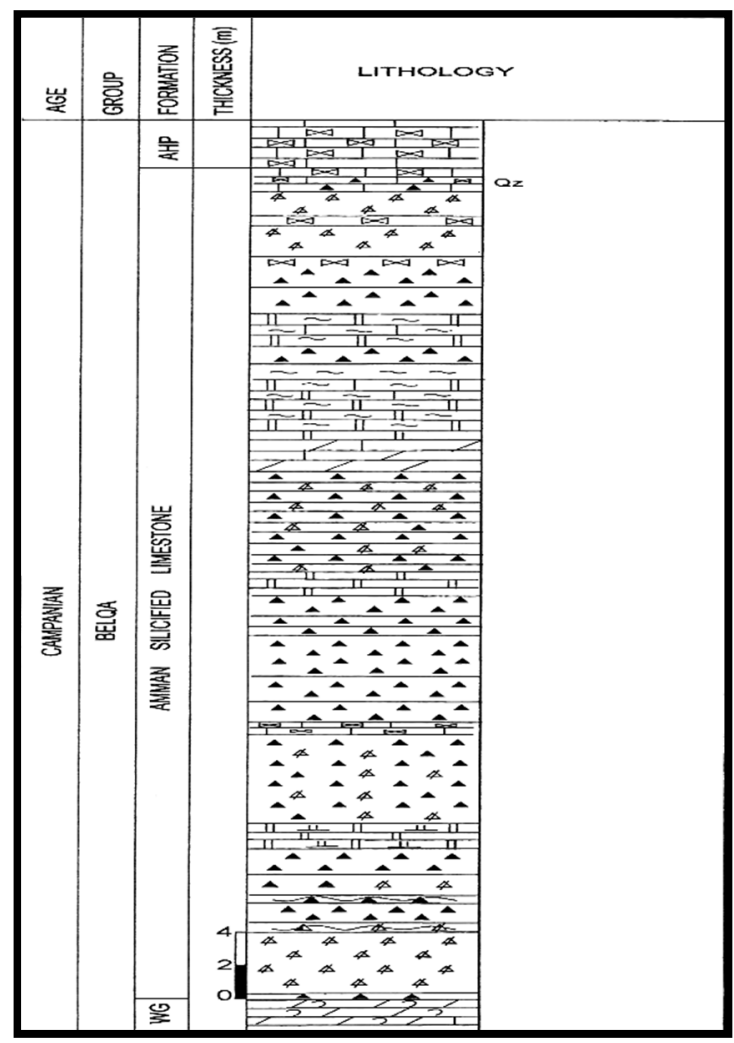

Figure 7. Graphic log of the Amman Silicified Limestone Formation in the study area

\subsubsection{Al Hisa Phosphorite Formation (AHP)}

The formation has a broad distribution in the study area. It is exposed in different areas in the northwestern (Ail and Basta villages.), central and in southwestern parts of the study area. The formation has not been subdivided in this study due to the limit of the sections thickness, while in central Jordan, Al Hisa Phosphorite Formation includes 4 members: Siwaqa Coquina, Sultani Phosphorite, Bahiya Coquina and Qatrana Phosphorite (Table. 1). The formation is characterized by soft lithology due to the presence of high proportion of soft marl, phosphate and phosphatic limestone and this is reflected in its gently slopping morphological features (Fig. 8). 


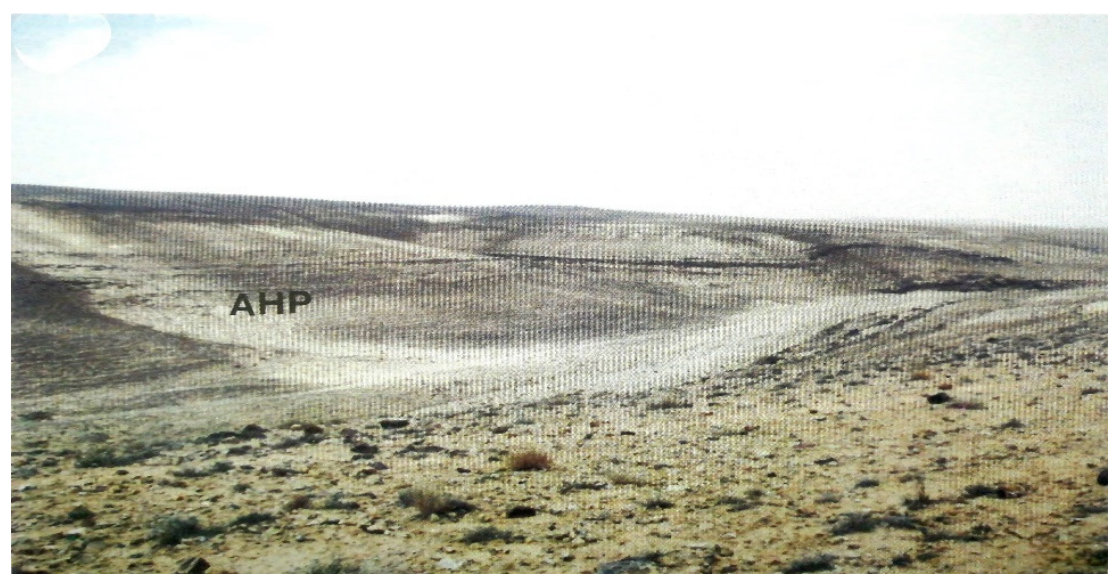

Figure 8.Expousure of Al Hisa Phospherite Formation(AHP).

The formation consists of phosphate, phosphatic chert, phosphatic limestone, chert, microcrystalline limestone, coquina, phosphatic sand and thin layers of quartzite are recognized (Fig. 9.). Phosphatic beds of this formation have a maximum percent of $27 \%$ P2O5, sampled east of Murrigha village. The maximum recorded thickness of this formation is up to 50m near Murigha village. Variation in thickness and lithology were recognized in the area due to the lateral facies. The macrofauna includes well preserved bivalves (Oyster sp.), gastropods, Turittela sp., fish teeth, poorly preserved bones and different types of fish fragments. Wetzel \& Morton (1959) indicate an age of Campanian for this formation, while Bender (1974) gave Campanian-Maastrichtian age. The Jordanian phosphate was deposited in the transitional zone between stable shelf in the south and the Tethys Sea in the north by upwelling currents (Bender 1974). Tarawneh \& Moumani (1998) studied the phosphate in Naqib Etaiq in southeastern part of Jordan and they concluded that the contained fauna in addition to the higher amount of siliciclastics in this sequence indicate that the phosphorites in the southeastern part of Jordan were probably deposited in marginal marine environment; upper shoreface, very close to the shorelines of the continent.

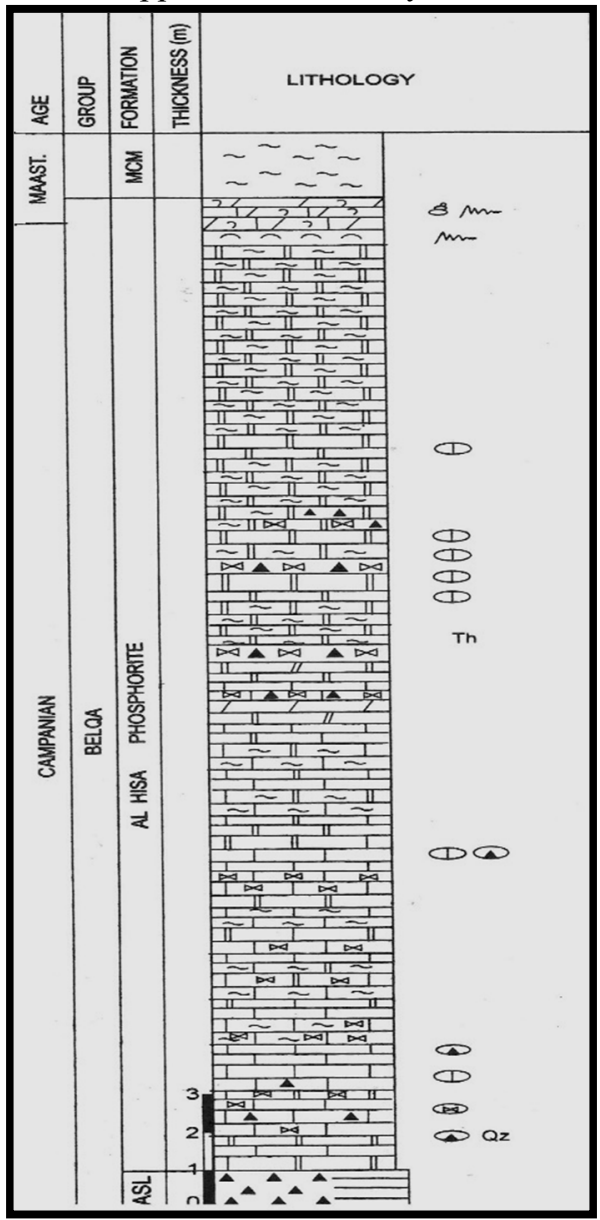

Figure 9. Graphic log of Al Hisa Phosphorite Formation in the study area. 


\subsubsection{Muwaqqar Chalk Marl Formation (MCM)}

The formation crops out mainly in the northern, southeastern and central parts of the study area. The absence of stratification, morphology, tone and dendritic drainage pattern are prominent features which distinguish this formation on aerial photographs and in the field.

Masri (1963) was the first to use the name of this formation after Muwaqqar area $35 \mathrm{~km}$ southeast of Amman. A composite section of this formation was measured in two localities in the northern part of the study area. The lower part comprises massive yellowish white, creamy and pink marl and chalky marl with primary and secondary gypsum or calcite filling the veins and cracks. Thin layers of marly limestone, chalky limestone and phosphate are present at the basal part of the formation. The upper part of this formation consist of green marl, dark green fissile bitumineous marl, phosphatic limestone, limestone concretions and overlain by yellowish pink, green marl, chalky limestone and fissile tan green marl at the top (Fig. 10).

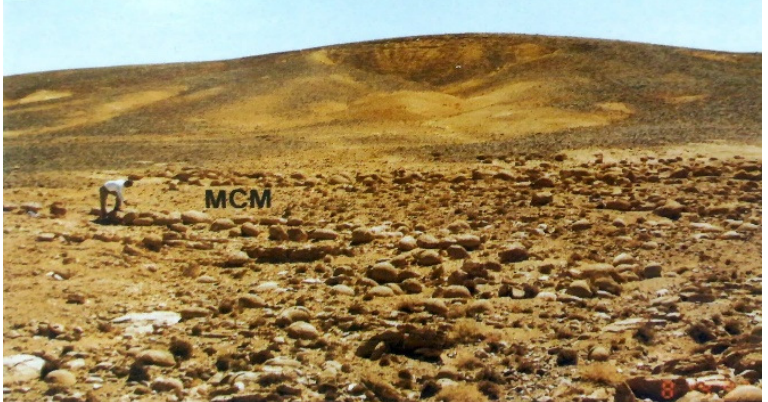

Figure 10. Exposure of the Muwaqqar Chalk Marl Formation (MCM).

The maximum exposed thickness of the Muwaqqar Chalk Marl Formation in the study area is 50m, which represents the lowermost and uppermost parts of this formation (Tarawneh \& Moumani 1998). The macrofauna contain sparse ammonite, Baculite sp., bivalves, shark teeth, gastropods and Thallassinoids burrows. The Muwaqqar Chalk Marl Formation contains high diversity of microfaunal content (Moumani 1997). The biota indicates that this formation is of Maastrichtian-Palaeocene age. Powell (1989) suggest a moderate to deep-water pelagic environment due to the predominant of the chalk and marl in this formation, in addition to the absence of the diverse benthic macro fauna and the presence of diverse planktonic fauna and erosional surfaces.

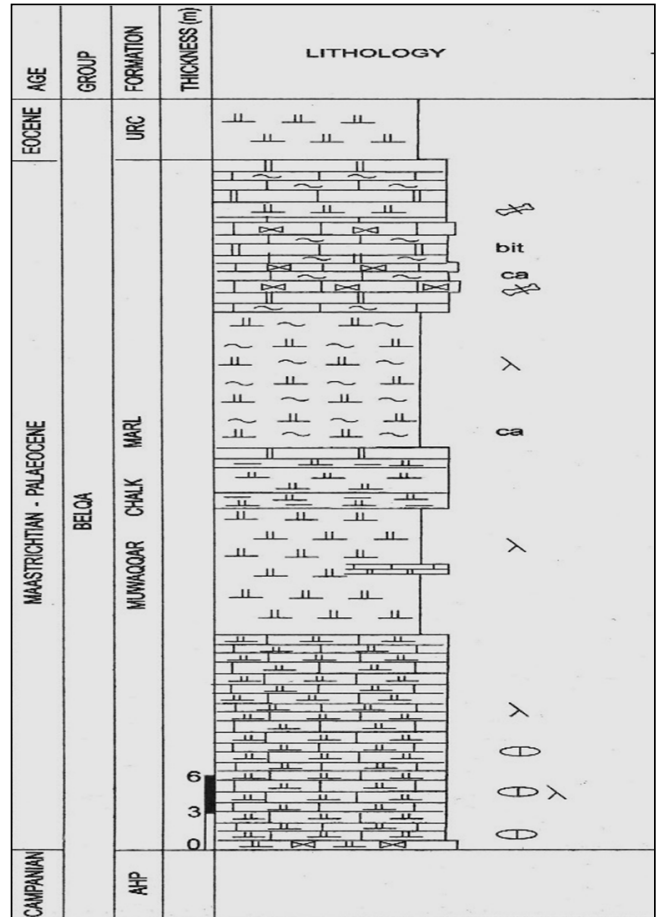

Figure 11. Graphic log of the Muwaqqar Chalk Marl Formation in the study area.

3.2.2.5 Umm Rijam Chert Limestone Formation (URC)

The formation represents the uppermost part of the Belqa Group in the study area. It crops out extensively in the northeastern and central parts of the area and present as continuous hills in Jibal El Jithe, Al Wuhayda, Samna and around Ma'an City, and along Isfir El Mahata sheet area. Small outcrops of this formation are exposed near and 
east of El Muraygha village. It forms conspicuous scarp feature and mesas above the Muwaqqar Chalk Marl Formation. The predominance of chert, chalk and hard limestone beds produce distinctive landform with steep slopes (Fig. 12). The uniform escarpment of this formation was incised by wadis retreated east and southeastwards.

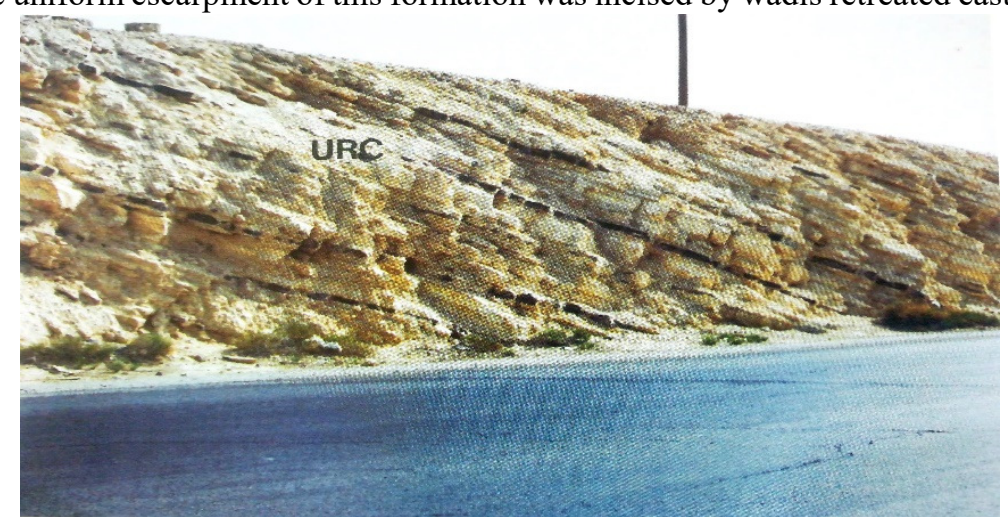

Figure 12. View of Umm Rijam Chert Limestone Formation (URC)

URC represents the uppermost unit of the Belqa Group. The formation predominantly consists of chalk, bedded chert; and limestone that produce a distinctive landform with gentle slopes (Fig.13). A prominent cliff (5$10 \mathrm{~m}$ thick) consisting of chalky, chalky limestone, marly limestone and clayey marl marks the lower part of this formation. The middle part consist of chalk, chalky limestone, phosphatic limestone, thin layer of phosphatic concretions $(0.1-0.3 \mathrm{~m})$ with the P2O5 content ranges from 18.8 to $31.19 \%$ (Tarawneh \& Moumani 2006). The upper part of the formation is predominantly limestone interbedded with chalk and limestone. The macrofossils are very sparse in this formation. The absence of benithic foraminefera in addition to the predominance of calcareous nanoplankton, and uniform lithologies of chalk, chert and limestone which developed over a wide area, suggested a deep water pelagic environment (Powell 1989). The presence of Nummulitic gizehensis in the Ma'an and Gharandal areas, suggests a Middle Eocene age Wetzel \& Morton (1959) and Upper Eocene Bender (1974). Subaqueous marine transgression drowned emergent highs led to deposition of such nummulitic limestone in the study area.

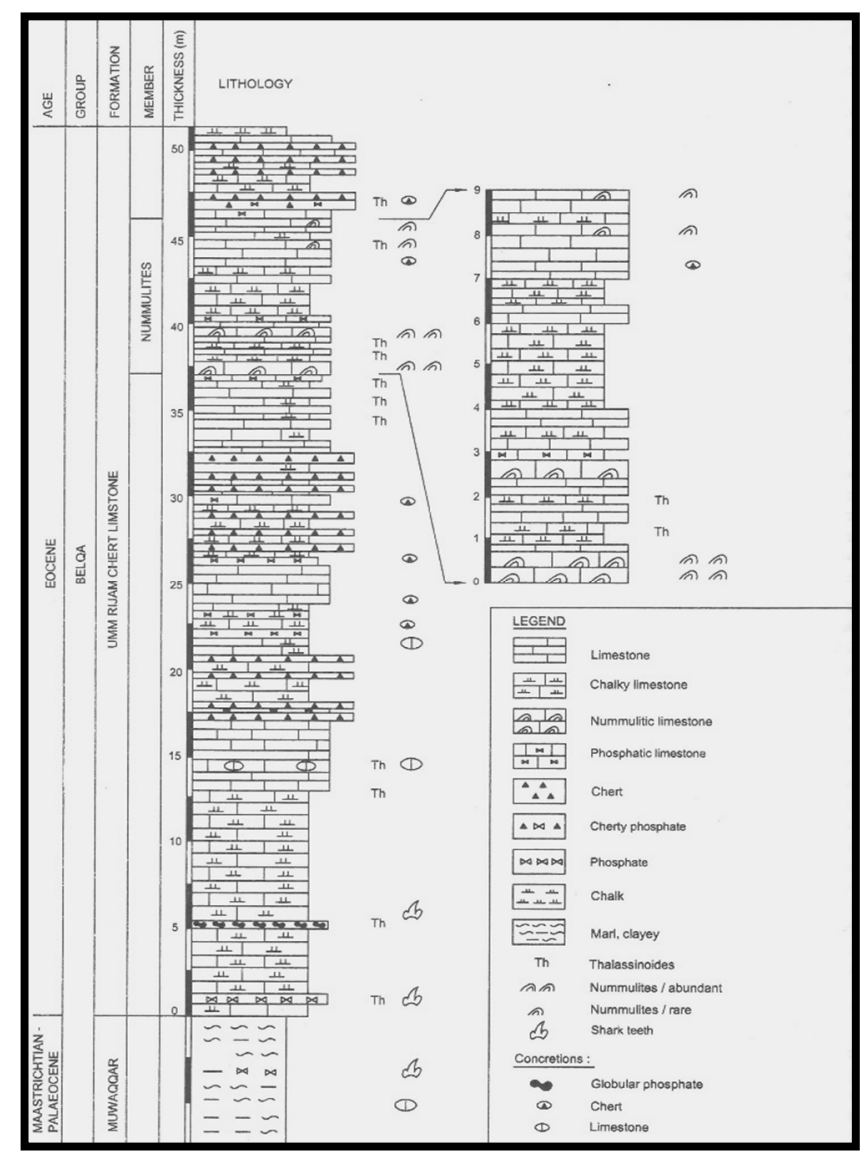

Figure 13. Graphic log of Umm Rijam Cher Limestone Formation in the study area. 


\section{Quaternary Sediments}

\subsection{Lake Sediments}

Quaternary and lake sediments are characterized by yellowish white weathering surfaces. The green marl and silt of the lake sediments that show yellowish green weathering surfaces are capped by calcrete that exposed in many parts of the lakes and is very distinctive. No terminology has been applied to these sediments, whereas similar sediments were mapped in central Jordan as Wadi Hasa Marl Formation (Moumani 1996a; Moumani 1997; Moumani 1996b; Makhlouf et al. 2015). The lake sediments are made up of predominantly alluvial and lacustrine sediments including conglomerate, marl and calcrete (Fig. 14). The lake sediments were logged by the author and geologist Khaled Moumani in different localities in the study area (Fig. 15).

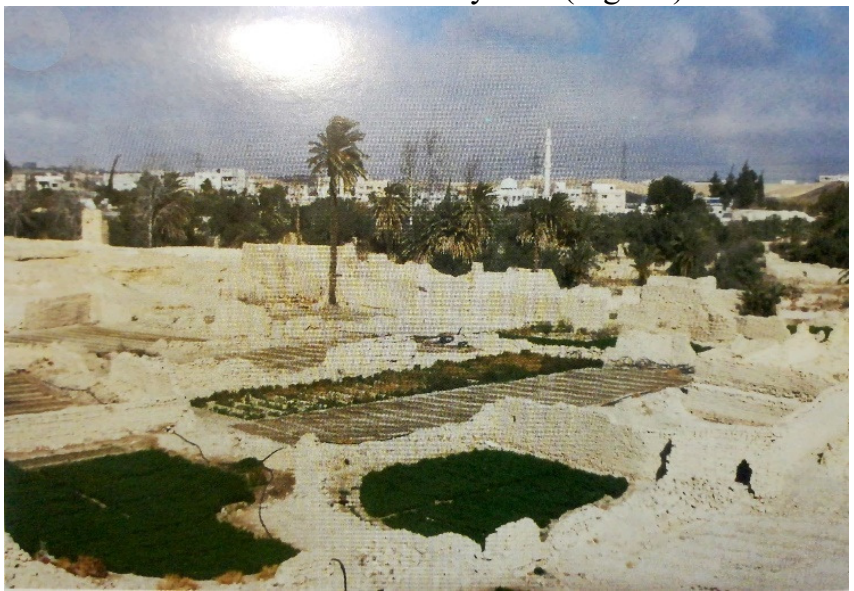

Figure 14. Exposure of the lake deposits in Ma'an city

The sediments can be subdivided into three main lithofacies; conglomerates, marl and silt, and calcrete. (i) Conglomerate Lithofacies; (ii) Marl and Silty Lithofacies and (iii) Calcrete Lithofacies (Moumani 1997; Moumani 1996a). No fossils have been observed in the conglomerates, whereas fossils are common in the marl and silt lithofacies. The vertical changes from conglomerate at the base to marl and calcrete with the presence of local gravel lenses indicate episodic change in the environment and suggest wet and dry periods of greater rainfall and/or run off. The marl and prismatic calcretes are interpreted to be of lacustrine origin. The prismatic calcretes are probably of marsh or lake limestone origin that were overprinted by pedogenic fabrics, whereas the nodular and conglomeratic calcrete are probably of pedogenic origin (Moumani 1997; Moumani 1996a; Makhlouf et al. 2015; Tarawneh 2002).

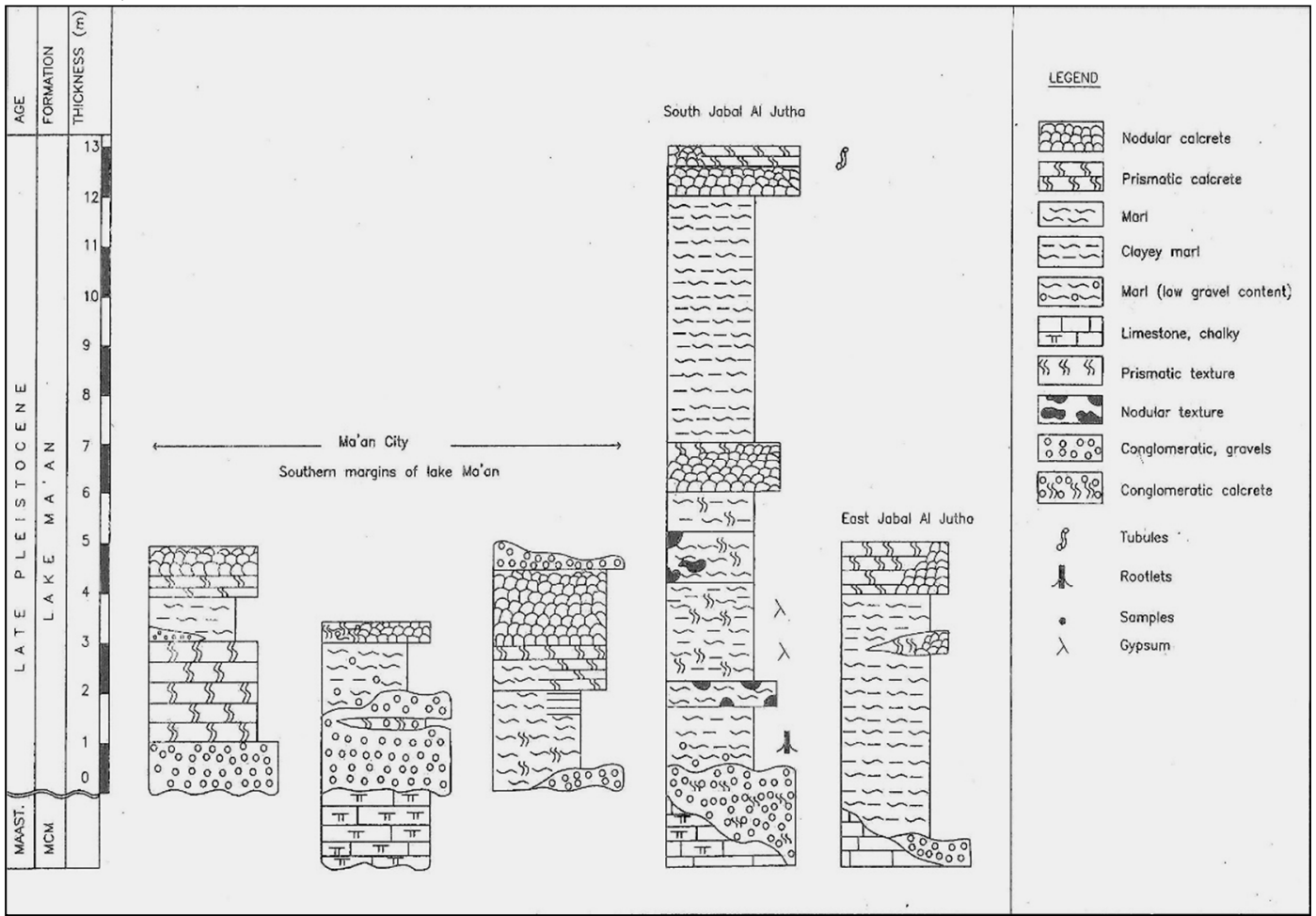

Figure 15. Graphic log of the lake sediments in the study area. 


\subsection{Superficial Deposits}

Many parts of the study area are covered by Pleistocene and younger superficial deposits. Pleistocene and Holocene sediments were differentiated into Pleistocene gravels and alluvial sediments.

\subsection{Pleistocene Fluviatile Gravels}

Poorly sorted alluvial sediments consist of well-rounded to subrounded gravels of variable composition depending on the source area. Poorly sorted sediments are present on the hill slopes and consist of gravel, sand and silt. Poorly sorted Pleistocene gravels are present in different parts of the study area. Coarse-grained granules, pebbles, cobbles and boulders of different lithologies are present above the present-day drainage levels in the study area. The gravels are poorly sorted, angular to subangular, and subrounded with angular to subangular chert clasts.

\section{Structural Geology}

\subsection{Regional Structural Setting}

The regional dip of the Cretaceous strata is gently toward NE. Faults are the most important structural element present in the study area. Three major trends were recognized in the study area that have direction N-S, NE-SW and NW-SE (Fig. 16).

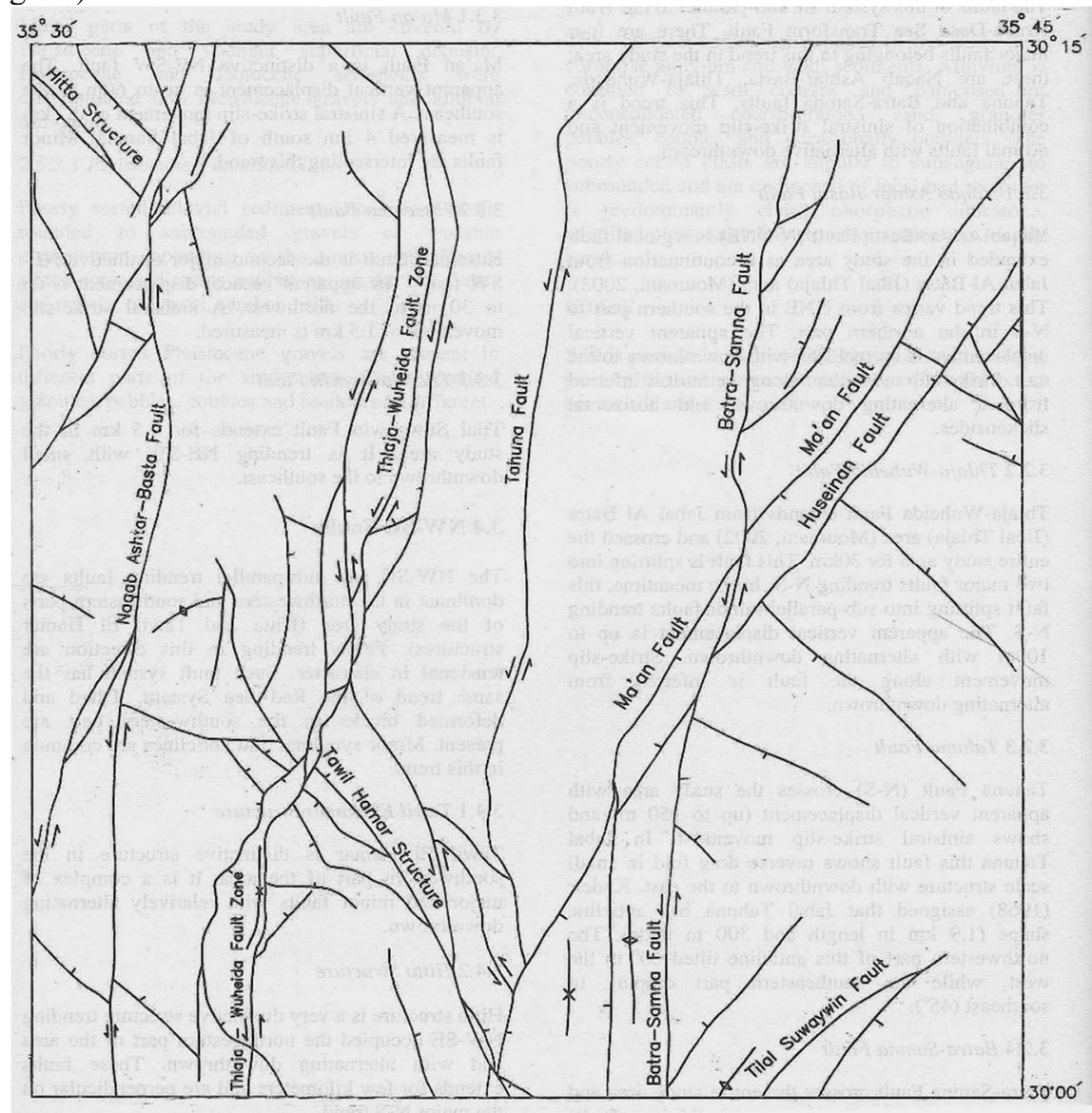

Figure 16. Structural map of the area, shows the major structure directions.

The N-S faults are sub-parallel to the Wadi Araba-Dead Sea Transform Fault. There are four major faults belonging to this trend in the study area; these are Naqab Ashtar-Basta, Thlaja-Wuheida, Tahuna and Batra-Samna faults. This trend is a combination of sinistral strike-slip movement and normal faults with alternative downthrown. There are three major faults with NE-SW direction crosses the study area; these are Ma'an, El Huseinan and Tilal Suwaywin faults. These faults extend for tens of kilometers and cross the nearby sheet areas.

The NW-SE and sub-parallel trending faults are dominant in the northwestern and southeastern parts of the study area (Hitta and Tawil El Hamar structures). Faults trending in this direction are tensional in character. Such fault system has the same trend of the Red Sea System. Tilted and deformed blocks in the southwestern part are present. Minor synclines and anticlines are common in this trend. Minor faults of different directions (N.NNE, NNW, NE and NW) are present and crosses the study area for few kilometers. These faults are with variable thrown direction and amount of vertical displacement. Folds is of minor consequence in the study area. These folds occur as small monoclines and synclines that present in restricted areas. folds are trending mostly to the N-S and 
plunging in the same direction.

A few symmetrical and asymmetrical anticlines and synclines, trending N-S and NE-SW are present mainly in the southwestern and western parts of the study area. Most of these are sub-parallel to the main fault trend. A major flexure is present in northwestern part of the area, north of Basta and Ail villages. This flexure extends for $4 \mathrm{~km}$ and trending N-S.

\section{Conclusion}

The importance of this study is due to the fact that Jordan is witnessing an expansion in investment in the extractive and exploration industries, and Ma'an Governorate is considered as a huge reservoir of mineral and industrial rocks that will play an important role on mining industries in Jordan. Distribution of the rocks in the study like phosphate, limestone, coquina, clay, dolomite, sandstone, oil shale and different types of aggregates are the main source for many industries in Jordan. It can be considered that the diversity of these industrial minerals and rocks is the future of many extractive and manufacture industries. Ma'an area is mostly covered by sedimentary rocks spanning from Turonian-Eocene to Quaternary age. Sedimentation in the study area during the Mesozoic and early Cenozoic times was controlled by the configuration of the Tethys Sea and eustatic fluctuations of Arabian-Nubian Shield. For the objectives of this work, field data were collected during systematic field trips. Representative samples of the sedimentary rocks exposed in the study area were collected and examined in the laboratory including petrographic and mineralogical examinations. The Wadi As Sir Limestone, Wadi Umm Ghudran, Amman Silicified Limestone and Al Hisa Phosphorite formations dominate the northwestern and southwestern parts and partly in the central part of the study area. The overlaying Muwaqqar Chalk Marl (Maastrichitian-Paleocene) and Umm Rijam Chert Limestone (Eocene) formations covered broad areas of the study area. Shallow lakes are existed in many parts of the study area as well as in Ma'an City. Superficial sediments (Pleistocene to Recent) cover considerable parts of the study area and include alluvium, wadi sediments and lake sediments. N-S, NE-SW and NW-SE trending faults are the principal structural elements of the area. Folding and flexures with anticlines and synclines mostly trending NE-SW and N-S are present. The structural pattern in the area is controlled by the Dead Sea Transform Fault System.

\section{Acknowledgment}

The author would like to thank all colleagues at Natural Resources Authority for their cooperation during preparation of the materials for this research. Thanks are due to Khaled Moumani and Ahmed Masri from Natural Resources Authority for their fruitful discussion in the field and at the office. Thanks are due to Eng. Shorroq Salam and Eng. Hiba Basem from faculty of Engineering in Amman Arab University, for their help during preparation of this research. Thanks for anonymous reviewers for their comments.

\section{References}

Bender, F., (1974). Geology of Jordan: Berlin. Germany, Gebrüder Bornträger.

Burdon, D.J., (1959). Handbook of the Geology of Jordan: to accompany and explain the three sheets of 1: 250,000 Geological Map, East of the Rift, AM Quennell, Govt. Hashemite Kingdom of Jordan, 82p, Benham, Colchester.

MacDonald, S.M., M and partners (1965b) East Bank water resources. Hydrogeological Survey of the MadabaMaan area, 3 .

Makhlouf, I.M., Tarawneh, K., Moumani, K. and Ibrahim, K.M., (2015). Recognition of quartz geodes in the Upper Cretaceous Wadi Umm Ghudran Formation, Ras En Naqab, South Jordan. Arabian Journal of Geosciences, 8(3), pp.1535-1547 DOI 10.1007/s12517-014-1281-6.

Masri, M., 1963. Report on the geology of the Amman-Zerqa area. Central Water Authority, Amman, pp.1-74.

Morton, D.M. and Wetzel, R., (1959). Contribution a la Geologie de la Transjordanie. Notes et Memoires sur le Moyen-Orient. Contributions a la Geologie de la Peninsule Arabique, 7, pp.95-188.

Moumani, K., (1996). Quaternary sediments of the Jurf Ed Darawish area, Central Jordan (Doctoral dissertation, University of Wales, Cardiff). Department of Earth Sciences, Unpublished M. Phil. Thesis, 181p.

Moumani, K., (1996). Quaternary sediments of the Jurf Ed Darawish area, Central Jordan (Doctoral dissertation, University of Wales, Cardiff).

Moumani, K., (1997). The Geology of Al Husayniyya Al Janubiyya (Jurf Ed Darawish) Area: Map Sheet No. 3151II. Hashemite Kingdom of Jordan, Natural Resources Authority, Geology Directorate, Geology Mapping Division.

Moumani, K., Alexander, J. and Bateman, M.D., (2003). Sedimentology of the late Quaternary Wadi Hasa Marl Formation of central Jordan: A record of climate variability. Palaeogeography, Palaeoclimatology, Palaeoecology, 191(2), pp.221-242.

MOUMANI, K., MASRI, A. and TARAWNEH, K., 2001. First Record Of An Enormous Drifted Fossil Tree Trunk From The Upper Cretaceous OfBatnAl GhulArea, SEJJordan. Jiyūlüjīyat Al-Urdun Wa-al-manātiq Al- 
mujāwirah, (6), p.41.

Moumani, K.A., (2000). The Geology of Jabal Al Batra'(Jibal Thlaja), Map Sheet (3149-IV), National 1: 50,000 Mapping Project. Natural Resources Authority, Geological Directorate, Mapping Division, Amman.

Parker, D.H., (1970). The hydrogeology of the Mesozoic-Cenozoic aquifers of the western highlands and plateau of east Jordan. UNDP/FAO, AG 2: SF (No. 2). Jor 9, Technical report.

Powell, J. H., (1989a). Stratigraphy and Sedimen-tation of the Phanerozoic rocks in Central and South Jordan, Part A: Ram and Khrayim groups, NRA, Geol. Dir., Map. Div., Bull 11a, Amman.

Powell, J.H., (1989). Stratigraphy and sedimentation of the Phanerozoic rocks in central and south Jordan. Division, Directorate, Authority, Ministry.

Tarawneh, K. and Moumani, K., (2006). Petrography, chemistry and genesis of phosphorite concretions in the Eocene Umm Rijam Chert limestone Formation, Ma'an area, south Jordan. Journal of Asian Earth Sciences, 26(6), pp.627-635.

Tarawneh, K. and Moumani, K., 1998. Geological and Mineralogical Studies on the Phosphorite Deposits in Naqib Etaiq/SE Jordan. In Proceeding of the 6 th Jordanian Geological Conference (pp. 19-33).

Tarawneh, K., (2002). Geological Map of Ma'an, National Mapping Project, Nat., Res., Auth., Geol. Dir., Map. Div., Amman Map Sheet No. 3150-III, 1:50,000. 